\title{
ETHNICITY AND UNEMPLOYMENT IN FINLAND
}

\author{
Jan Saarela \\ Akademi University, Finland \\ and Fjalar Finnäs \\ Åbo Akademi University, Finland
}

This research note provides the general findings from a research project analyzing the reasons behind the lower unemployment rate of the Swedish-speaking minority in Finland, compared with the Finnish-speaking majority. The main conclusion is that the unemployment gap cannot be attributed to ethnic-group differences in age, education, place of residence, or industrial structure. We believe that two latent factors are highly relevant in this context: language proficiency and social integration, although no data presently available provides information about such issues.

\section{Introduction}

The empirical literature on ethnic-group differences in labour market success and income has mainly been concerned with first or later generations of immigrants versus natives (see e.g. Chiswick, 1977; 1978; Borjas, 1985; 1987; 1992; 1993; 1994). In most such comparisons, discrimination and inherent ability differences explain the higher unemployment risk and the lower income of the minority group.

Some ethnic groups, however, challenge the traditional view (Becker, 1957) on minorities and labour market discrimination. For example, American-born Chinese, Japanese and Jews are successful in the U.S. labour market (Brenner and Kiefer, 1981, Chiswick, 1983a, 1983b, Sowell, 1981), whereas unem- 
ployment of Welsh-speakers is lower than that of English-speakers in Wales (Drinkwater and O'Leary, 1997). Characteristic differences (in age, education, geographical location, etc.) cannot, however, fully explain the disparities. The reasons behind these contradictory findings therefore have not been fully understood. It is plausible that latent cultural differences may be important.

Besides the majority of Finnish-speakers in Finland, there is an (native) ethnic minority group of Swedish-speakers, which constitutes barely six percent of the total population (barely 300,000 individuals). Only about 1.7 percent of the population has a native language other than Finnish or Swedish. The Swedish-speakers all live along the southern and western coastlines of the country, about half of them in municipalities (kommuner) where they form the local majority (see Figure 1).

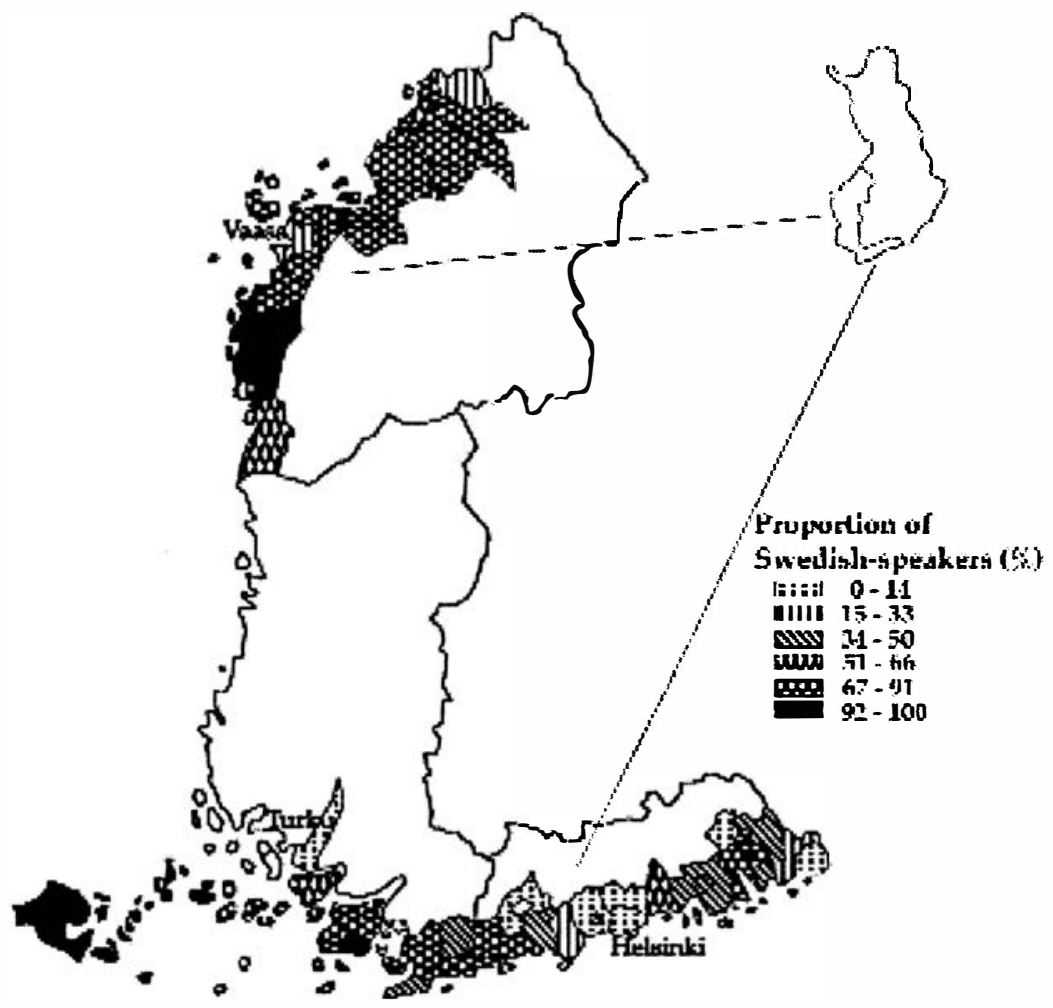

Figure 1. The geographical concentration of Swedish-speakers in Finland (1990) 


\section{Ethnic Studies Review Volume 25}

Studies have shown that Swedish-speakers have better health and live longer than Finnish-speakers (see e.g. Finnäs, 1986; Saarela and Finnäs, 2002a). In addition the unemployment rate of Swedish-speakers is lower than that of Finnishspeakers. On a national level, the unemployment rate in 1990 was about 2.6 percent for Swedish-speakers and about 5.7 percent for Finnish-speakers. During the 1990s Finland experienced an economic recession during which unemployment increased dramatically; however ethnic-group differences in unemployment rates remained. In 1995 the unemployment rate of Swedish-speakers was 11.4, whereas among Finnish-speakers it was 19.3. In 1998 the corresponding numbers were 7.9 and 14.9. No successful attempts have been made to explain these ethnic-group disparities empirically.

The bilingual parts of Finland also experience the lowest unemployment rates. In counties (län; the three larger geographical areas in the above figure) with both Swedish-speaking and Finnish-speaking residents the unemployment rate was 2.9, 15.3 and 10.2 in 1990, 1995 and 1998, respectively. In the corresponding years the overall unemployment rate in the other counties in Finland was 7.3, 21.5, and 17.7.

Reasons behind the difference in unemployment rates between Swedish-speakers and Finnish-speakers in Finland previously has not been analyzed. The present research note will provide the main findings of a research project analysing this issue (Saarela and Finnäs, 2001; 2002b). In order for the reader to better understand the interpretation of the results, we start with providing an overview of the Swedish-speakers' situation in Finland.

\section{The Swedish-Speaking Ethnic Minority in Finland}

Municipalities in Finland are either bilingual or monolingual. A municipality is classified as bilingual if the minority exceeds 8 percent or 3,000 inhabitants. In a bilingual municipality people are entitled to use either Finnish or Swedish with local authorities (i.e., local authorities must provide service in both languages).

The roots of the Swedish-speaking community in Finland go far back in history. For several centuries Finland was integrated 
and an equal part of the realm of Sweden. Swedish was then the dominant language of government, business, and culture. In 1809, when Finland became a part of the Russian Empire, the Swedish-speaking population was about 15 percent of the total population. It was, however, not until the end of the 19th century that the Finnish language achieved equal status with Swedish. According to the Constitution Act of 1919 Finnish and Swedish have equal status as official languages. In 1917 Finland declared its independence. In the 1920s and 1930s attitudes towards the Swedish-language issue sharpened, but the wars against the Soviet Union in 1939-1940 and 1941-1944 united the two ethnic groups.

The Swedish-speaking ethnic minority (ethnicity is defined on the basis of native language) is guaranteed constitutional rights and is covered by a considerable organizational and institutional network. This institutional support is political and educational, as well as cultural.

The national awakening of Swedish-speakers at the end of the 19th century generated a number of institutions which still have great vitality. A Swedish-language political party was founded, the Swedish People's Party (Svenska Folkpartiet). This non-socialist party has in general elections attracted over 70 percent of all Swedish-speaking voters. The party has also been represented in most governments since Finland's independence. It has been more influential than its size and has protected fairly successfully the interests of the Swedish-speakers. At present it has twelve of the two hundred seats in the Finnish Parliament. The party has one representative in the present national government and one member in the European Parliament. Also the other (more dominant, Finnish-speaking) political parties have operations in Swedish.

Another important political pressure group that protects the interests of Swedish-speakers is the Swedish Assembly of Finland (Svenska Finlands Folkting). It represents a cross-section of political opinion and receives financial support from the Government.

Bilingual municipalities are required to provide schools for both language groups. There is a school system that can offer teaching in Swedish from elementary up to university level. One 


\section{Ethnic Studies Review Volume 25}

Swedish-speaking university ( $\AA$ bo Akademi), several bilingual universities, and a number of tertiary-level institutions guarantee teaching at the highest education level. Swedish is a compulsory subject at Finnish-speaking comprehensive schools, as is Finnish at Swedish-speaking comprehensive schools.

There are also other important institutions. One of the brigades of the Finnish defense forces provides instructions in Swedish (Nylands Brigad). Most young Swedish-speaking males do their compulsory military service within this brigade. There is a diocese for Swedish-speaking parishes in the EvangelicalLutheran Church to which 85 percent of the population belong. Swedish-speaking free-church communities are also numerous. Moreover, there are Swedish-speaking co-operative organizations within agriculture, banking, insurance, book publishing, fur trading, and retail business, as well as Swedish-speaking cultural foundations and associations.

Swedish-speakers have a fairly extensive cultural life, which includes theatres, newspapers and sports associations. The Finnish Broadcasting Company (YLE) maintains two radio channels and one TV-channel that are Swedish-speaking. Numerous books and magazines are also published in Swedish.

It is thus fairly evident that the institutional network constitutes an important element for the vitality of the ethnic minority group of Swedish-speakers in Finland.

\section{Research Results}

Statistics Finland (Statistikcentralen) maintains register data of the total population of Finland, including information on personal characteristics, such as age, gender, education, municipality of residence, labour market status, etc. These registers also include a language variable, which indicates the unique mother tongue of each citizen; consequently empirical research must not be undertaken on the basis of samples (only). We have used data consisting of cross sections at the end of the years 1990, 1995 and 1998 of the total Swedish-speaking and Finnish-speaking population of Finland aged twenty-sixty to sixty-four (about three million individuals per year). Due to the geographical concentration of Swedish-speakers and regional differences in unemployment rates we have restricted the data to the bilingual 
part of the country, i.e. the geographical area that consists of the bilingual municipalities.

It is reasonable to argue that ethnic-group differences in unemployment may be due to differences in labour force participation and (or) between-group differences in personal characteristics, such as age, education, and municipality of residence. Our empirical analyses could, however, not find any support for the hypothesis that Swedish-speakers and Finnish-speakers differ with regard to labour force participation. We therefore concentrated our subsequent analyses on labour force participants (employed and unemployed). However the unemployment gap between Swedish-speakers and Finnish-speakers decreased only marginally when we controlled for the impact of age, education, gender, and municipality of residence. The results indicated that there is an ethnic-group difference in the odds for being unemployed, of about 30 percent.

It also would be reasonable to assume that ethnic-group differences in industrial distribution, i.e. the fact that Swedishspeakers and Finnish-speakers to some extent work in different industries, may explain the unemployment gap. In order to test such a hypothesis, we also have used panel data (an extract from the Finnish Longitudinal Census Data File). The analysis results suggested that the effect of (the most recent) industry of work has a significant impact on unemployment, but only to a very limited extent explains the ethnic-group difference.

A third type of data including time spent unemployed in the local labour market Vaasa indicated that Swedish-speakers have shorter unemployment spells than Finnish-speakers. In relation to the above findings we could conclude that there also must be an ethnic-group difference in the inflow into unemployment (which we have not been able to observe explicitly).

In our empirical analysis we have accounted for the effects of a number of socio-demographic characteristics as well for the municipality of residence. Still there is a substantial unemployment gap between Swedish-speakers and Finnish-speakers which we have not been able to explain; therefore we will discuss some other plausible explanations although we emphasize that we cannot test them empirically with presently available register data. 


\section{Alternative Explanations}

We believe two latent factors are highly relevant when one compares Swedish speakers with Finnish speakers with regard to unemployment: language proficiency and social integration.

Higher language proficiency implies higher individual productivity, while higher level of social integration, i.e. more extensive social networks (cf. Coleman, 1988; Montgomery, 1992), induce a more efficient job search. Language skills could make it easier for a person to become employed, because he or she is assumed to have a higher individual productivity than a person without language skills (cf. McManus et al., 1983). More and better social networks, in terms of friends and other personal contacts, reduce the time spent searching for a job (cf. Blau and Robins, 1990; Wadsworth, 1991).

It is commonly thought that Swedish-speakers to a higher extent than Finnish-speakers are bilingual, i.e. that they speak both Swedish and Finnish fluently. There is no Finnish data that would provide information about language proficiency (nor about social integration) linked to individual labour market outcomes. There is, in fact, very little known about individual bilingualism in Finland. No recent data exist that would provide information about individual language proficiency. There is a census from 1950, which included a question about knowledge of Finnish and Swedish, and a smaller survey directed to the Finnish population in 1987 (cf. Sandlund and Björklund, 1980; Sandlund, 1991). The 1950 census clearly indicated that bilingualism was much more frequent among Swedish-speakers. Whereas about half the Swedish-speaking population considered themselves to be bilingual, fewer than one-third of the Finnish-speakers, in the bilingual area, did. In bilingual municipalities with a Finnish-speaking majority, more than 80 percent of the Swedish-speakers considered themselves to be bilingual. The survey from 1987 found that, in general, knowledge of Swedish among Finnish-speakers has increased; however fewer than half of the Finnish-speakers living in the bilingual area considered themselves to be reading and speaking Swedish "well" or "rather well." Due to the migration of Finnish-speaking individuals into the bilingual area, Swedish-speakers have more and more become a local minority, but there are no reasons to 
believe that knowledge of Finnish among Swedish-speakers has decreased.

Another notable issue in the present context is the existence of bilingual families. More than 30 percent of the younger Swedish-speakers have a bilingual family background. Only 5 percent of the Finnish-speakers, in the bilingual area, come from bilingual families (Finnäs, 2000). We are confident that most Swedish-speakers with a bilingual background speak Finnish fluently. Individual bilingualism would consequently favour Swedish-speakers in the labour market.

There is also the issue of employment discrimination, implying that persons with identical productive characteristics are treated differently because of the ethnic group to which they belong (cf. Ehrenberg and Smith, 1994, 402). Half the population of Swedish-speakers live in municipalities where they form the local majority. Finnish-speakers could, being a minority in such areas, be discriminated against; however it is plausible that language proficiency requirements are higher in areas with a higher proportion of Swedish-speakers. This would benefit Swedishspeakers in their job search, since they to a greater extent are bilingual than Finnish-speakers. There are some indications that ethnic-group differences in unemployment increase with the proportion of Swedish-speakers in a municipality. We cannot adjudicate between these two explanations, although we doubt that they fully explain the ethnic-group difference in unemployment.

The other latent factor that may explain the unemployment gap between the two ethnic groups is social integration (or social capital). This concept is hard to quantify. No adequate empirical measure has yet been established. Putnam (1993; 1995), for example, has argued that there is reciprocal relationship between community level involvement and trust in others, which induces a high level of social integration in a society (subpopulation). This will in turn manifest in the attributes and activities (e.g. the unemployment situation) of individuals who live in such a society.

We believe that there is a higher degree of social integration among Swedish-speakers than among Finnish-speakers (see also Hyyppä and Mäki, 2001a; 2001b). Besides the institutional sup- 


\section{Ethnic Studies Review Volume 25}

port discussed in the previous section, which is important in this context, two other aspects suggest there being a higher degree of social integration in the Swedish-speaking population. Within the bilingual area geographical mobility has been higher among Finnish-speakers. In 1995 about 80 percent of the Finnish-speakers aged 20-34 lived in the same area as they did in 1990, while the corresponding figure among the Swedish-speakers was as much as 95 percent. If the length of an individual's stay in a region is positively correlated with the degree of social integration, this may induce a more favourable position for Swedishspeakers. A fairly common argument is that all Swedish-speakers "know each other."

Secondly, it is plausible that ethnic-group differences in divorce rates may be an indication for differences in the level of social integration. The divorce rate among Swedish-speakers is almost half that of Finnish-speakers (Finnäs, 1997).

Finally, we want to point out one aspect that might be assumed important but which we do not believe has any major impact. One could argue that ethnic-group differences in unemployment are the results of a sorting process (cf. Weiss, 1995), induced by emigration. It is a well-known fact that emigration, foremost to Sweden, was very strong in the 1960s and 1970s, and that it was much more frequent among Swedish-speakers than among Finnish-speakers (Finnäs, 1986, 1994). The similar relationship between ethnicity and emigration still exists, although the emigration flows are much smaller. This may be assumed to generate a sorting process where a higher proportion of Swedish speakers than Finnish speakers emigrate instead of being or becoming unemployed. The implication would then be a higher average productivity and thus better labour market performance among non-emigrating Swedish-speakers than among non-emigrating Finnish-speakers. However we believe that migration flows have a very small impact on the unemployment gap between the ethnic groups, because Finnish-speakers are much more mobile than Swedish-speakers with regard to longdistance migration within the country (Finnäs, 1994). Also migration out of the bilingual area is much more frequent among Finnish-speakers, which consequently contradicts the sorting hypothesis. 
Based on the discussion above, there are good reasons for Swedish-speakers to have lower unemployment rates than Finnish-speakers. As stated earlier, there is no obvious way for us to differentiate empirically between potential effects induced by language proficiency and social integration. We do not therefore claim that our empirical results will be specifically in favour of any of these factors.

A main advantage of using large register data sets is that it provides the opportunity to reject (with certainty) some aspects as being explanations. Additionally the method of approach clearly raises a number of other interesting research questions, for example that of how to measure potential ethnic-group differences in social integration. One way to proceed with such analyses would be to use data including a number of potential indicators for social networks, such as participation in different social activities. An attempt to construct survey data concerned with language proficiency of each ethnic group would be another avenue. In any case, we believe that our research results may be of interest to an international audience.

\section{References}

Blau, D.M. \& Robins, P.K. (1990). "Job Search Outcomes for the Employed and Unemployed." Journal of Political Economy, 98, 637655.

Borjas, G. (1985). "Assimilation Changes in Cohort Quality and the Earnings of Immigrants." Journal of Labor Economics, 3, 463-489.

(1987). "Self-selection and the Earnings of Immigrants." American Economic Review, 77, 531-553.

(1992). "Ethnic Capital and Intergenerational Mobility." Quarterly Journal of Economics, 107, 123-150.

(1993). "The Intergenerational Mobility of Immigrants." Journal of Labor Economics, 11, 113-135. 


\section{Ethnic Studies Review Volume 25}

(1994). "Immigrant Skills and Ethnic Spillovers." Journal of Population Economics, 7, 99-118.

Brenner, R. \& Kiefer, N. M. (1981). "The Economics of the Diaspora: Discrimination and Occupational Structure." Economic Development and Cultural Change, 29, 517-533.

Chiswick, B. R. (1977). "Sons of Immigrants: Are They at an Earnings Disadvantage?" American Economic Review, 67, 288-325.

(1978). "The Effect of Americanization on the Earnings of Foreign-born Men." Journal of Political Economy, 86, 897-919.

(1983a). "An Analysis of the Earnings and Employment of Asian-American Men." Journal of Labor Economics, 1, 197-214.

(1983b). "The Earnings and Human Capital of American Jews." The Journal of Human Resources," 18, 313-336.

Coleman, J. (1988). "Social Capital in the Creation of Human Capital." American Journal of Sociology, 94, 95-120.

Drinkwater, S. J. \& O'Leary, N. C. (1997). "Unemployment in Wales: Does Language Matter?" Regional Studies, 31, 581-591.

Finnäs, F. (1986). Den Finlandssvenska Befolkningsutvecklingen 19501980 - En Analys av en Språkgrupps Demografiska Utveckling och Effekten av Blandäktenskap. Doctoral Dissertation. Skrifter Utgivna av Svenska Litteratursällskapet i Finland, No. 533. Helsinki.

(1994). "Language Shifts and Migration - The Finnish Longitudinal Census Data File as an Aid to Social Research." Studies, No. 209. Statistics Finland, Helsinki.

(1997). "Social Integration, Heterogeneity, and Divorce: The Case of the Swedish-speaking Population in Finland." Acta Sociologica, 40, 263-277.

(2000). Tvåspråkiga Familjer i Statistikens Ljus. Forskningsrapport, No. 37. Åbo Akademi University, Institutet för Finlandssvensk Samhällsforskning.

Hyуррӓ, M. T. \& Mäki, J. (2001a). "Why Do Swedish-speaking Finns 
have Longer Active Life?" An Area for Social Capital Research. Health Promotion International, 16, 55-64

(2001b). "Individual-level Relationships

between Social Capital and Self-rated Health in a Bilingual Community." Preventive Medicine, 32, 148-155.

McManus, W., Gould, W. \& Welch, F. (1983). "Earnings of Hispanic Men: The Role of English Language Proficiency." Journal of Labor Economics, 1, 101-130.

Montgomery, J. D. (1992). "Job Search and Network Composition: Implications of the Strength-of-Weak-Ties Hypothesis." American Sociological Review, 57, 586-596.

(1995). “Bowling Alone: America's Declining Social Capital." Journal of Democracy, 6, 65-78.

Saarela, J. \& Finnäs, F. (2001). "Ethnicity, Industrial Structure and Unemployment in Finland." Mimeo (December). Åbo Akademi University, Department of Social Sciences.

(2002a). "Language-group Differences in Very Early Retirement in Finland." Mimeo (March). Åbo Akademi University, Department of Social Sciences.

Sandlund, T. (1991). "Bilingualism in Finland - Ethnicity and Mobility." Papers, No. 17. SLS Nämnd för Samhällsforskning, Helsinki.

Sandlund, T. \& Björklund, K. (1980). "Bilinguals in Finland 1950 Ethnicity and Mobility." Papers, No. 5. SLS Nämnd för Samhällsforskning, Turku.

Wadsworth, J. (1991). "Unemployment Benefits and Search Effort in the UK Labour Market." Economica, 58, 17-34.

Weiss, A. (1995). "Human Capital vs. Signalling Explanations of Wages." Journal of Economic Perspectives, 9, 133-154. 